\title{
CRYPTOGAMS IN A HORTICULTURAL SETTING IN SCOTLAND
}

\author{
Roy Watling
}

The exhibiting of living cryptogams at the Royal Botanic Garden, Edinburgh and Dawyck Botanic Garden is described with the hope that from the management procedures experienced, other institutions will follow and demonstrate to the public these important components of our natural heritage.

\section{INTRODUCTION}

In 1992 a Cryptogamic Garden was established at the Royal Botanic Garden, Edinburgh (RBGE). This was almost certainly the first garden of its kind to be constructed in an institute such as this and it was completed in a little more than two years. Once it was decided to construct such a garden a suitable choice of location had to be found which did not interfere with existing plantings. It also had to fit into the long term planning of the Garden and still be accessible to the general public. A suitable location was ear-marked and later developed in the rather shaded and consequently rather damp north west part of the Garden next to an inhospitable wall separating the Garden from a domestic dwelling.

\section{DESIGN AND CONSTRUCTION OF THE CRYPTOGAMIC GARDEN}

Horticultural projects were part of the Diploma in Horticulture taught at Edinburgh (now replaced by the HND/BSc in Horticulture with Plantsmanship) and the design for such a concept was ideal for consideration. Roland Whiteman DHE, then a student, saw the potential and enthusiastically joined the team to create a Cryptogamic Garden. Ideas were drawn-up, discussed at length and then redrawn as the garden had to have robust horticultural principles as well as exhibiting cryptogams. The concept of the latter had to be realised on paper and then made into a natural looking garden area with year round interest, as fungi generally only give interest during the autumn when they fruit.

Bill Tait a supervisor in the Herbaceous Department at that time was assigned to oversee the implementation of the horticultural aspects of the project. Native trees from a number of sources as far apart as Aviemore, Inverness-shire to Saltoun Big Wood, East Lothian were lifted with as generous a soil ball as possible. This not only enabled successful re-planting but also allowed retention of the soil mycorrhizal components in addition to potential litter and wood rotters, also referred to as saprotrophs. It was

${ }^{1}$ Roy Watling is a retired mycologist from the Royal Botanic Garden Edinburgh and is now Director of Caledonian Mycological Enterprises.

Address: 20A, Inverleith Row, Edinburgh EH3 5LR 
considered of paramount importance to do this as plants live in association with fungi and supply them with valuable nitrogen and phosphorus nutrients. The associations are fundamental yet complex and interact with the other soil organisms as demonstrated by subsequent work at the Dawyck Cryptogamic Sanctuary described below. The trees included Alnus glutinosa (Alder), Fraxinus excelsior (Ash), Sambucus nigra (Elder) and Sorbus aucuparia (Rowan) which have symbiotic fungi within their root cells, and Betula pendula (Birch), Corylus avellana (Hazel), Quercus robur (Oak) and Pinus sylvestris (Scot's pine) which possess sheathing mycorrhiza where the fungus forms an envelope around the root-tips. Many of these trees were but a few years old and were lifted with as little damage as possible to the surrounding wild vegetation. The saplings were planted in pre-excavated holes larger than the size of the root system filled with well-rotted compost incorporated into the lower spit prior to planting.

The trees were planted irregularly to give the effect of a natural setting through which meandered a path of shredded bark and then tree stumps, felled limbs and branches were scattered throughout. This gave the envisaged sylvan scene with the wood debris acting as a habitat for a range of lignicolous fungi. Permission was also obtained from a number of land owners to lift a range of wild plants. These included Luzula sylvatica (Wood Rush) and Teucrium scorodonium (Wood Sage) to give foliage effect and, from the leaf litter arose Oxalis acetosella (Wood Sorrel), Anemone nemorosa (Wood anemone), Adoxa moschatellina (Moschatel), Ajuga reptans (Bugle), Geum urbanum (Wood Avens), Geranium robertianum (Herb Robert), Primula spp. and Viola spp. All were introduced to give spring flowering, and all have successfully naturalized. For summer flowering Scrophularia nodosum (Figwort), Succisia pratensis (Devil's Bit Scabious) and Lonicera periclymenum (Honeysuckle) were planted out.

The ferns were lifted as crowns during late winter and once they had started to grow the following spring they were planted out in well-rotted leaf mould in groups of related species to allow visitors to obtain an idea of their classification. Equisetum spp. (Horsetails) such as Equisetum sylvaticum (Wood Horsetail) from the garden's existing collections, which were excess to requirements were also planted out. To provide humidity the ferns and horsetails were sprayed daily during the warmer, drier days of late summer to aid establishment.

The ferns included Blechnum spicatum (Hard Fern), Athyrium filix-femina (Lady Fern), Dryopteris filix-mas (Male Fern), and D. dilatata (Broad Buckler Fern). The Male Fern was used to form a dramatic border to the woodland area. The Oak Fern, Gymnocarpium dryopteris, was introduced with leaf-mould and planted in and around a limestone outcrop, a feature which had been built for lime-loving plants. Phyllitis scolopendri (Hart's Tongue Fern) was also planted in this area and Ophioglossum vulgatum (Adder's Tongue) was planted around the outcrop with Asplenium ruta-muraria (Wall-rue). The Royal Fern, (Osmunda regalis) was planted in a wet depression which had been made to encourage leaves to accumulate and thus to attract leaf litter fungi. 
Many of the introduced logs and stumps and some of the rocks were covered in mosses and a very decaying trunk on which Dryopteris affinis was growing was carefully transported and added to the under-storey.

Most of the trees, shrubs and herbaceous plants were permanently labelled but because of the ephemeral nature of the fungi, except for some woody bracket species, these were only labelled when and where they fructified, usually later in the season. In fact, until they produced their impressive, sometimes bizarre, fruiting bodies they could not be labelled and this caused a problem in that staff were frequently unavailable at the exact time necessary to produce a label despite the fact that the fungus might only fruit for a few days. Gradually a set of labels of the commoner fungi was accumulated. Continual labelling is necessary to maintain the usefulness of such a garden.

The Cryptogamic Garden proved to be a success from the start judging from the interest from the general public after its official opening by Magnus Magnusson, then Chairman of Scottish Natural Heritage and also a TV naturalist and media presenter. It was so successful that an Ecological Garden demonstrating Scottish vegetational types was added onto the eastern border linking the Cryptogamic Garden with the formal Order Beds. In addition, on the other side of the main path through the Demonstration Garden the adjacent formal Rose Garden was converted into a natural feature with an extensive planting of birch. This time, however, it was the trees that formed the delimitation to a hummocky grassland which has now shown, as hoped, the development of pasture fungi in the autumn, in addition to some aliens which may have been introduced many years ago from Australia. This 'extension' blends into a demonstration bed of dwarf arctic willows which includes many of the species which clothe the tops of the highest mountains in Scotland. Finally, as part of the Garden's much later Scottish Rare Plant Project the Cryptogamic Garden offered a protected and favourable habitat in which to cultivate Polygonatum verticillatum (Whorled Solomon's Seal).

\section{DAWYCK CRYPTOGAMIC SANCTUARY AND RESERVE}

Although the Cryptogamic Sanctuary and Reserve at Dawyck Botanic Garden is very different in nature from the Cryptogamic Garden in Edinburgh it was firmly based on the success of the Edinburgh project. Officially opened in September 1996 by the Earl of Selborne, it expanded the ways in which to exhibit cryptogams but this time in an already well defined natural setting. With the financial restraints of the 1990s it became quite clear that Heron Wood, situated on the southern boundary of the garden at Dawyck would not be developed as part of the main garden in the foreseeable future and so it became a prime candidate for consideration.

Heron Wood was an old beech plantation with scattered Quercus pedunculata (Volunteer Oak), Betula verruscosa (Birch), and a few specimen Ilex aquifolium (Holly). Other plantings were of Tilia x europea (Linden) and Pseudotsuga menziesii (Douglas Fir) on the northern fringe and along the south west edge, Abies alba (Silver 


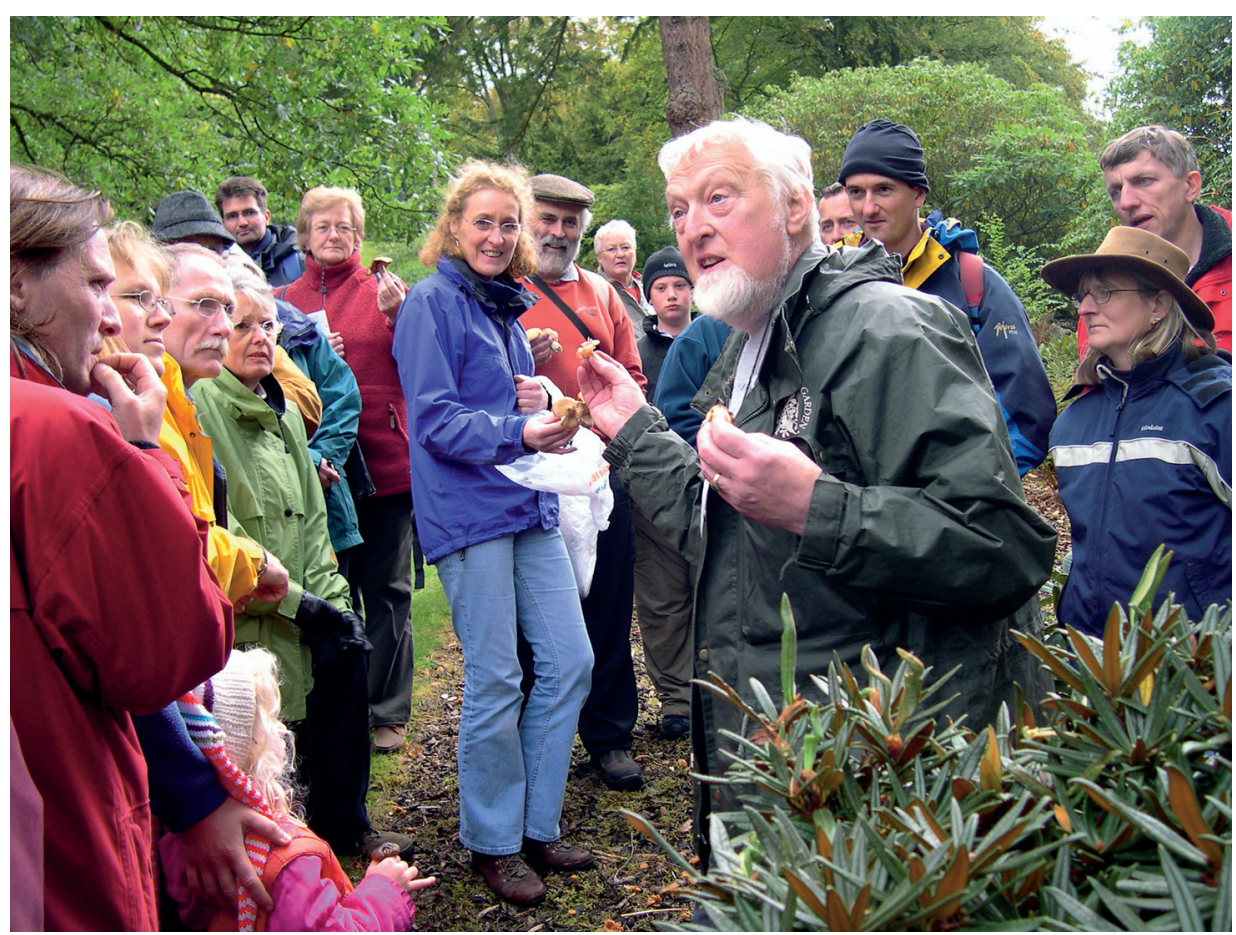

Fig. 1 Fungus foray in Heron Wood Cryptogamic Sanctuary with Roy Watling. Photo: David Knott.

Fir) and Pinus sylvestris subsp. scotica (Scots Pine), the latter from seed collected at Braemar, Aberdeenshire over 150 years ago. Sometime during the last twenty years an invasion of birch from the neighbouring property has encroached into the beech planting but inexplicably stopped half way through it. In addition, as the wood was used to rear pheasants for the estate's sport, a small clearing, now colonized by Holcus mollis (Creeping Soft Grass), was created. Such a wide range of different plant communities made Heron Wood an ideal location for the proposed Sanctuary. Here the habitat was basically left alone, even to the extent of not clearing away fallen trees, while in the Reserve part where minimal management has been undertaken only when absolutely necessary. The Reserve forms a wedge which sweeps around a grove of old Scot's Pine on which several uncommon lichens for Scotland occur and links the Sanctuary to the Scrape, a small stream issuing from the surrounding hills, which bisects the Garden. The total area is about 7.5 hectares with two thirds dedicated to the Sanctuary.

The cost of the design and fabrication of demonstration boards to explain to the public the groups of cryptogams which might be seen in the Sanctuary and Reserve was paid by a number of interested bodies. After a 'pump primer' grant from the Richard Jennings Conservation Fund of the British Mycological Society during its centenary year was procured, other groups wished to take part. These included the British Bryological 
Society, British Lichen Society, Botanical Society of Scotland, Friends of the RBGE and Plantlife International. Excess funding was used in the purchase of a chalet constructed at the western edge of the Sanctuary within the Reserve. This allows the area to be appreciated, even in inclement weather. The short fall in cost was made up by a generous gift from Philip Booth of Sheffield, Yorkshire who was intrigued by the establishment of a trial 'biodiversity plot' in which fungi and other organisms and soil factors were to be monitored throughout the year.

The biodiversity plot is $100 \mathrm{~m}^{2}$ within which are a number of $8 \times 10$ metre square smaller monitoring plots. After 12 years, work based around the biodiversity plots has resulted in the completion of several student projects as part of degrees from the University of Abertay and has attracted researchers from abroad. A summary of these studies can be seen in the published Sir William Wright Smith lecture, a lecture given to commemorate a former Regius Keeper of the Edinburgh garden and himself keenly interested in the Dawyck policies (Watling, 2005). The Heron Wood Project is used on a regular basis for teaching postgraduate students, especially those who are on the University of Edinburgh/RBGE MSc degree in The Biodiversity and Taxonomy of Plants and the University of Edinburgh degree in Botany. At least two forays are held annually at Dawyck for the general public with one strongly based on Heron Wood. In this way ecological concepts and the role of fungi in plant ecosystems can be described and demonstrated. Heron Wood has hosted the British Mycological Society, Plantlife Scotland, British Lichen Society, Institute of Biology (Scottish Branch), Institute of Horticulture and the Linnaean Society, in addition to serving as a place in which to launch Government Biodiversity plans and Scottish Natural Heritage publications. Heron Wood has therefore had extensive press coverage and has been the subject of television and radio programmes.

Various donations from interested individuals and careful spending after the launch allowed three brochures to be prepared - one on the Heron Wood Project, a second on the Biodiversity Project within the Heron Wood Programme and one on Larger Fungi. The number has been expanded through cooperation with the Publications Department at RBGE to include one on lichens, one on mosses, one on micro-fungi and galls and one on the rather special and uncommon larger fungi found at Dawyck. In fact there are 1,055 different species of fungi found within the Dawyck policies with over one third found in Heron Wood. This last figure is based on records up to 1 January 2007 but there is also information for lichens, mosses and liverworts, vascular plants, mites, nematodes, spring-tails, soil ciliates and amoebae. Climatic and edaphic data adds to the data-set making Heron Wood probably the best documented area in Britain if not Europe. Fifteen publications in both scientific and general biological journals have resulted from the Dawyck study. More recent funding from Scottish Natural Heritage has allowed the original demonstration panels to be redesigned by the RBGE interpretation staff and set in place to continue the educational aspect of this Border's woodland area which commenced twelve years ago (Fig. 2). 


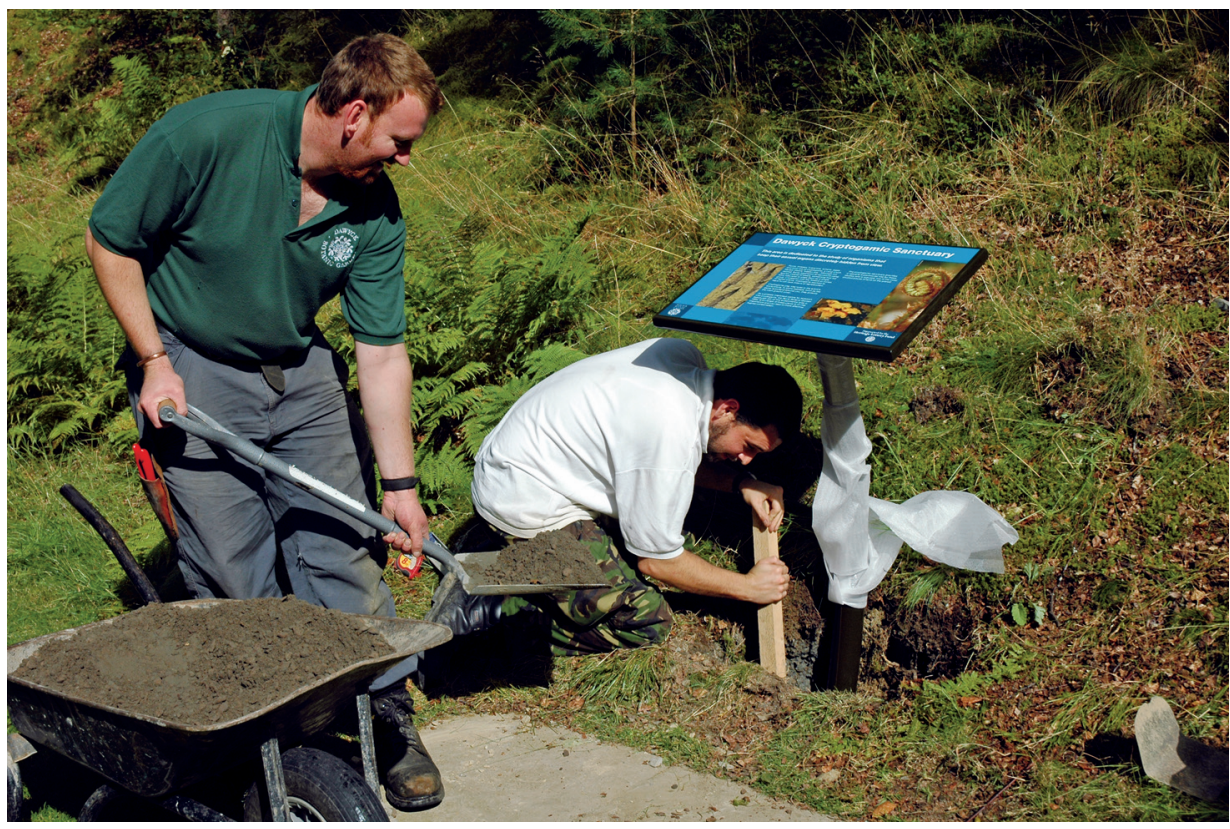

Fig. 2 Staff installing interpretive signage in the Heron Wood Cryptogamic Sanctuary. Photo: David Knott.

\section{REFERENCE}

WATLING, R. (2005). Dawyck Botanic Garden: The Heron Wood Cryptogamic Project. Botanical Journal of Scotland 56(2): 109-118. 